\title{
Knockdown resistance in pyrethroid-resistant horn fly (Diptera: Muscidae) populations in Brazil
}

\author{
Resistência Knockdown em populaçóes de mosca-dos-chifres do Brasil resistentes aos piretróides \\ Gustavo A. Sabatini ${ }^{1 *}$; Paulo E. M. Ribolla ${ }^{2}$; Antonio T. M. Barros ${ }^{3}$; \\ Felix D. Guerrero ${ }^{4}$; Terezinha T. S. Schumaker ${ }^{1}$ \\ ${ }^{1}$ Departamento de Parasitologia, Instituto de Ciências Biomédicas - ICB II, Universidade de São Paulo - USP \\ ${ }^{2}$ Departamento de Parasitologia, Instituto de Biociências, Universidade Estadual Paulista - UNESP \\ ${ }^{3}$ Centro de Pesquisa Agropecuária do Pantanal - CPAP, Empresa Brasileira de Pesquisa Agropecuária - EMBRAPA, Corumbá - MS, Brazil \\ ${ }^{4}$ Knipling - Bushland US Livestock Insects Research Laboratory, United States Department of Agriculture, \\ Agricultural Research Service USDA / ARS, Kerrville - TX, United States of America
}

Received March 25, 2008

Accepted August 25, 2009

\begin{abstract}
To investigate the $k d r$ (knockdown resistance) resistance-associated gene mutation and determine its frequency in pyrethroid-resistant horn fly (Haematobia irritans) populations, a total of 1,804 horn flies of 37 different populations from all Brazilian regions (North, Northeast, Central-West, Southeast, and South) were molecular screened through polymerase chain reaction (PCR). The $k d r$ gene was not detected in $87.08 \%$ of the flies. However, the gene was amplified in $12.92 \%$ of the flies, of which $11.70 \%$ were resistant heterozygous and $1.22 \%$ were resistant homozygous. Deviation from Hardy-Weinberg equilibrium (HWE) was found only in 1 ranch with an excess of heterozygous. When populations were grouped by region, three metapopulations showed significant deviations of HWE (Central-West population, South population and Southeast population). This indicates that populations are isolated one from another and $k d r$ occurrence seems to be an independent effect probably reflecting the insecticide strategy used by each ranch. Although resistance to pyrethroids is disseminated throughout Brazil, only $48 \%$ of resistant populations had $k d r$ flies, and the frequency of $k d r$ individuals in each of these resistant populations was quite low. But this study shows that, with the apparent exception of the Northeast region, the $k d r$ mechanism associated with pyrethroid resistance occurs all over Brazil.
\end{abstract}

Keywords: Haematobia irritans, horn fly, resistance, pyrethroid.

\section{Resumo}

Com o objetivo de verificar a ocorrência e determinar a frequência da mutaçáo $k d r$ (knock down resistance) em populaçôes de Haematobia irritans (mosca-dos-chifres) resistentes aos piretróides, foram analisados 1.804 indivíduos de 37 populaçóes de todas as Regiôes do Brasil. Com exceção da Região Nordeste, o kdr (knock down resistance gene) foi encontrado em populaçôes de todas as regióes. A mutação não foi detectada em $87,08 \%$ dos indivíduos. Entretanto, o gene foi amplificado de $12,92 \%$ das moscas, das quais $11,70 \%$ se mostraram heterozigotas resistentes e 1,22\% homozigotas resistentes. Em todas as populaçóes verificou-se equilíbrio de acordo com a Lei de Hardy e Weinberg, exceto uma com excesso de heterozigotos. Entretanto, quando agrupamos diferentes populaçóes numa metapopulaçâo de acordo com a regiáo geográfica, é possível observar um desvio nas populaçôes Centro-Oeste, Sul e Sudeste, indicando isolamento populacional e que a ocorrência do $k d r$ é provavelmente um efeito independente, talvez refletindo a estratégia de uso do inseticida de cada produtor. Apesar da resistência aos piretróides estar disseminada por todo o país, apenas $48 \%$ das populaçóes resistentes apresentaram o $k d r$, e a frequência de indivíduos $k d r$ nas populações resistentes se mostrou bastante baixa. À exceção da Região Nordeste, o mecanismo de resistência ligado ao kdr ocorre em todo o país.

Palavras-chave: Haematobia irritans, mosca-dos-chifres, resistência, piretróides.

\footnotetext{
${ }^{*}$ Corresponding author: Gustavo A. Sabatini

Departamento de Parasitologia, Instituto de Ciências Biomédicas - ICB II,

Universidade de São Paulo - USP

Av. Lineu Prestes, 1374, CEP 05508-900 São Paulo - SP, Brazil

e-mail: gasaba@usp.br
} 


\section{Introduction}

The horn fly, Haematobia irritans irritans, is considered one of the most economically important cattle ectoparasites due to its widespread distribution and effect on cattle. Horn flies cause stress and reduction in rate of weight gain, efficiency of feed utilization and milk production by bovine hosts (CAMPBELL, 1976; KINZER et al., 1984) as well as hide damage (GUGLIEMONE et al., 1999). Economic losses caused by horn flies in Brazil have been estimated in US\$ 150 million per year (GRISI et al., 2002).

To minimize economic losses to cattle producers, insecticides are used for fly control. But this practice leads to the development of insecticide resistance, which has been detected to active ingredients of all chemical classes commercially available up to the 1970's, except insect growth regulators. Horn fly resistance, mostly to pyrethroids, has been found throughout the American continent, including the US (SPARKS et al., 1985), Canada (CAMPBELL; THOMAS, 1992), Mexico (KUNZ et al., 1995), Uruguay (MÁRQUEZ et al., 1997), Argentina (GUGLIELMONE et al., 2001), and Brazil.

Although resistance to pyrethroids has been commonly documented, there have been relatively few studies regarding its mechanisms. One of the most important mechanisms of resistance to pyrethroids is the altered sensitivity of the target site, which is mediated by the $k d r$ (knockdown resistance) gene mutation (GUERRERO et al., 1997). Considering that the action site of pyrethroids is the sodium channel in the axon, it is expected that individual resistance to this chemical class involves a structural alteration on the gene that codes this site and/or the amplification of genes associated with the insecticide metabolism.

Changes in the sodium channel structure have been associated with pyrethroid resistance in Drosophila melanogaster (Meigen) (ARMICHOT et al., 1992), Blattella germanica (L.) (DONG; SCOTT, 1994), and Musca domestica (L.) (MIYASAKI et al., 1996). Guerrero et al. (1997) reported the cloning and sequencing of a fragment of $0.9 \mathrm{~kb}$ from the DNA region that encodes the sodium channel, and detected a nucleotide substitution in horn flies resistant to pyrethroids. The resulting amino acid change is exactly that seen in both $M$. domestica and B. germanica resistant to pyrethroids. Guerrero et al. (1997) developed a PCR assay to test individual horn flies for the presence of the $k d r$ pyrethroid resistance-associated sodium channel mutation. Resistance to pyrethroids, detected by insecticide bioassays, is widely spread in Brazil (BARROS, 2004). However, to date there is no published information regarding associated resistance mechanisms. The purpose of this study was to investigate the $k d r$ resistance-associated gene mutation and determine its frequency in pyrethroid-resistant horn fly populations from all Brazilian regions.

\section{Material and Methods}

\section{Fly collections}

From November 2000 to June 2002 horn fly samples were collected in cattle ranches from different Brazilian regions by an EMBRAPA (Brazilian Agricultural Research Corporation) team during a comprehensive study on horn fly susceptibility to insecticides. Few additional samples were collected in the State of São Paulo in 2005.

Ranches were randomly selected, depending basically on the occurrence of horn fly infestation on cattle and owner cooperation. Owners were asked to avoid insecticide treatments of cattle herds at least two weeks before sampling was conducted. In most situations no records of previous insecticide treatments were available at ranches but large use of synthetic pyrethroid products was common, while the use of insecticide from other classes was sporadic. Insecticides were mostly applied by manual backpack sprayers and the application of insecticide volumes lower than technically recommended was common in most ranches throughout the country.

Untreated cattle herds were brought to corral or cattle chutes depending on their infestation levels as well as proximity to the collection sites. No records from these animals were available.

Flies were randomly collected with hand nets from several infested animals and kept in a single net. A sample was transferred alive to plastic vials containing commercial ethanol (about 93-95\%) immediately after collection was finished. Fly samples were then sent to the Laboratory of Experimental and Applied Parasitology of Institute of Biomedical Science (ICB) at University of São Paulo (USP).

\section{Polymerase chain reactions}

Genomic DNA was isolated from individual adult horn flies as described by Aljanabi and Martinez (1997). The $k d r$ gene mutation was detected as proposed by Guerrero et al. (1998) using approximately $25 \mathrm{ng}$ of genomic DNA, 20 pmol of each primer (FG-129, FG-138, and either FG-130 or FG-134), 10 mM Tris (hydroxymethyl) aminomethane hydrochloride $\mathrm{pH} 8.3$, $50 \mathrm{mM} \mathrm{KCl}, 0.05 \mathrm{mM}$ each dNTP, $3.5 \mathrm{mM} \mathrm{MgCl}_{2}$, and $0.5 \mathrm{ul}$ Taq DNA polymerase ( 5 units per microliter of stock solution). Amplification was carried out using a thermocycler (Applied Biosystems; GeneAmp PCR System 2400) programmed for $96^{\circ} \mathrm{C}$ for 2 minutes; 35 cycles $\left(94^{\circ} \mathrm{C}\right.$ for 1 minute; $62^{\circ} \mathrm{C}$ for 1 minute); $72{ }^{\circ} \mathrm{C}$ for 1 minute and a final extension step $72^{\circ} \mathrm{C}$ for 7 minutes. PCR products were visualized on $1 \%$ agarose TBE gels stained by ethidium bromide under ultraviolet illumination.

\section{Statistical analyses}

Tests for deviations from HWE were performed by using the $\chi^{2}$ goodness-of-fit test. This calculation was performed according to McDonald et al. (1996).

\section{Results}

A total of 1,804 horn flies of 37 different populations from all Brazilian regions (North, Northeast, Central-West, Southeast, and South) were molecular screened for the $k d r$ gene. Except for the Northeast region, $k d r$ flies were found in populations sampled 


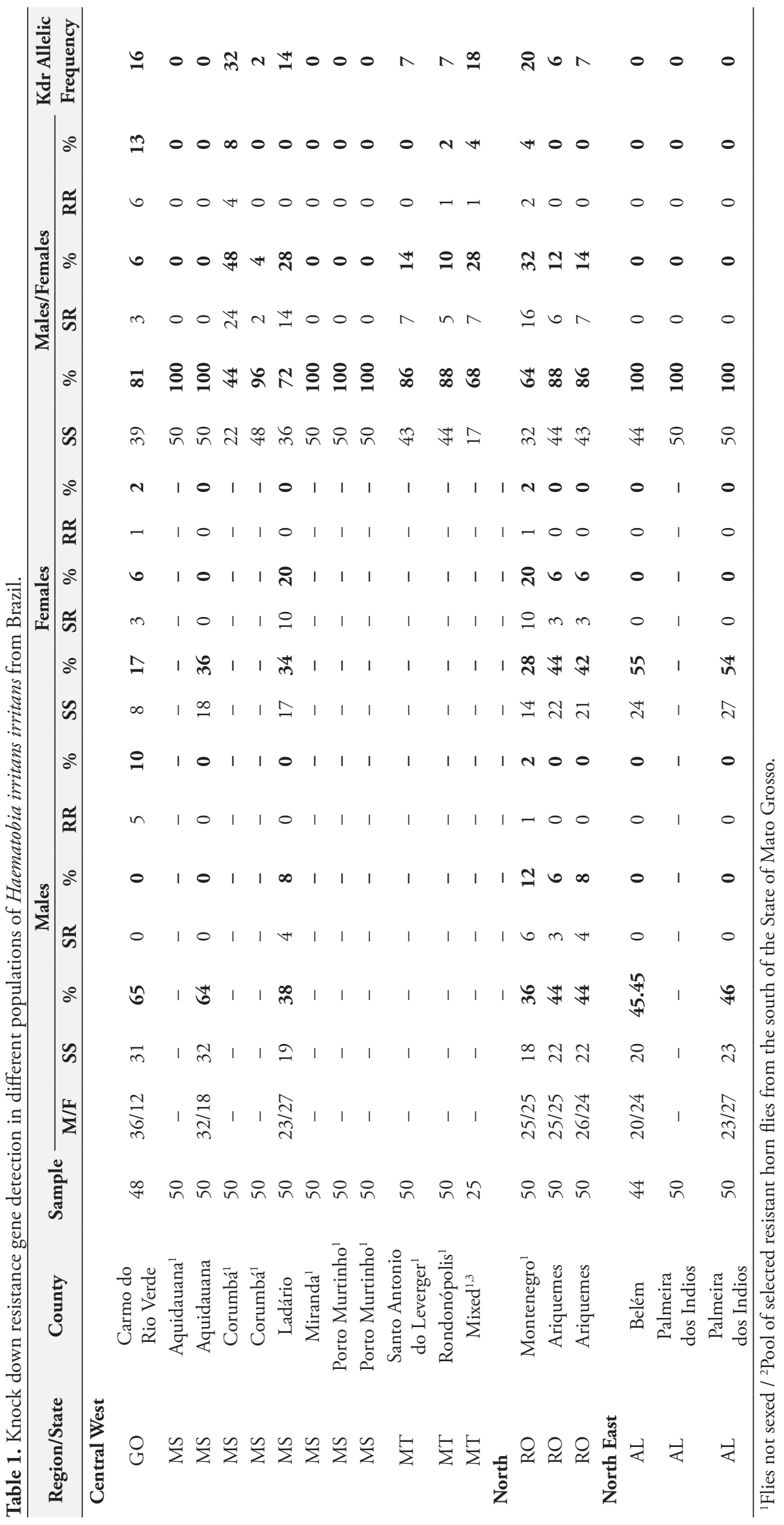




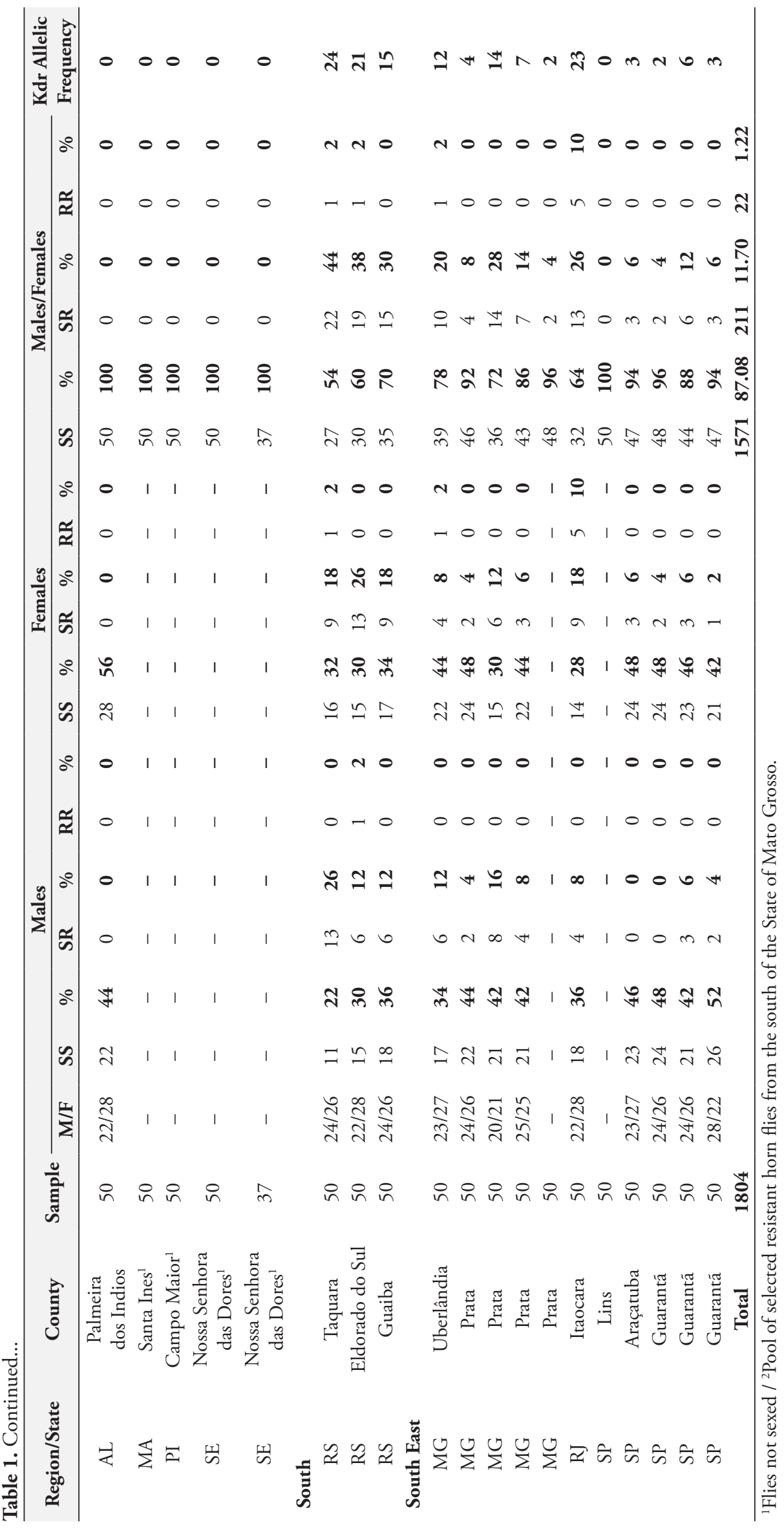


Table 2. Mean frequency of the knock down resistance gene in pyrethroid-resistant horn flies in Brazilian regions.

\begin{tabular}{lccccc}
\hline Region & Total of flies & \%SS & \%SR & \%RR & $\begin{array}{c}\text { Kdr Allelic } \\
\text { Frequency }\end{array}$ \\
\hline North East & 381 & 100 & 0 & 0 & 0 \\
South East & 350 & 81.27 & 11.64 & 1.09 & 6.09 \\
Central West & 573 & 76.27 & 19.33 & 2.21 & 1.33 \\
North & 150 & 69.33 & 37.33 & 1.33 & 11.00 \\
South & 150 & 61.33 & & 2000 \\
\hline
\end{tabular}

in all regions of the country. The $k d r$ gene was not detected in $1.571(87.08 \%)$ flies, considered as susceptible homozygous (SS). However, the gene was amplified in 233 (12.92\%) flies, of which $211(11.70 \%)$ were resistant heterozygous (SR) and $22(1.22 \%)$ were resistant homozygous (RR) (Table 1).

The average $k d r$ allelic frequency was calculated for each population (Table 1 ) and by region (Table 2). Allelic frequencies of the $k d r$ gene in the populations were relatively low, ranging from 0 to $32 \%$. Only four populations showed frequencies higher than $20 \%$.

$K d r$ resistant horn flies were found in 23 (62.16\%) out of 37 populations. Frequency of SR flies in the $k d r$ positive populations ranged from 4 to $48 \%$ and averaged 19\%. Although RR individuals were much less frequent, they were found in 9 (39.13\%) out of $23 \mathrm{kdr}$ positive populations, ranging from zero to $13 \%$ and averaging $1.96 \%$.

Specimens from 21 populations were sexed before the $k d r$ assay. No major differences in the $k d r$ frequency associated with fly gender were seen among these populations.

Deviation from Hardy-Weinberg equilibrium was found only in 1 ranch (Carmo do Rio Verde $(\mathrm{GO})$ with $\mathrm{p}<0.0005)$ with an excess of heterozygous. When populations were grouped by region, three metapopulations showed significant deviations of HWE (Central-West population $\mathrm{p}<0.0005$; South population $\mathrm{p}<0.05$; Southeast population $\mathrm{p}<0.005)$.

\section{Discussion}

Synthetic pyrethroids have been used as insecticides since early 1980's and have rapidly disseminated worldwide. According to SINDAN (2005) there are 91 products for horn fly control registered for cattle use in Brazil. About $75 \%$ of these products contain pyrethroids, including associations with other insecticides or synergists. Due to their relatively lower prices these products are usually the first option for cattle producers for horn fly control. Inadequate and excessive pyrethroid product applications have lead to the current resistance problem in Brazil (BARROS, 2004). Horn fly resistance to pyrethroids, detected by insecticide bioassays, has been reported in the South (GUGLIELMONE et al., 2001), Central-West, and North regions in Brazil. More recently, resistance to pyrethroids was detected in about $95 \%$ of horn fly populations from 14 states in all Brazilian regions (BARROS, 2004). This comprehensive study showed that pyrethroid resistance in horn flies has become spread in Brazil.
The allelic frequencies of $k d r$ gene in the populations were relatively low (0-32\%) and only four populations showed frequencies higher than 20\%. Guglielmone et al. (2002) found nearly 50\% of $k d r$ allelic frequency in a population treated with cypermethrin for years; this frequency dropped to $20 \%$ after no cypermethrin treatments during four years. Although $\mathrm{LC}_{50}$ reduction followed a decrease in the $k d r$ gene frequency from 121.6 to $5.8 \mathrm{ug} \cdot \mathrm{cm}^{-2}$, it was still eight times higher than the $\mathrm{LC}_{50}$ from the Kerrville susceptible strain (GUGLIELMONE et al., 2001) and it was not enough to reestablish cypermethrin efficacy.

In our study, from the 23 populations where $k d r$ was amplified, 20 showed RR individual frequency between zero and $4 \%$ and only three populations had more expressive frequencies of RR individuals (8, 10, and 13\%). Li et al. (2003) reported frequencies of SR flies in those populations between 22.6 and 30.6\%, while in Brazil, where pyrethroids have been widely used, the frequency range of SR flies was quite low, varying from 4 to $20 \%$ in 14 populations, from 21 to $30 \%$ in five populations and only in four it was higher than $30 \%$.

Although in almost all populations allele frequencies were in agreement with HWE, when we grouped different populations in a metapopulation by geographic region, we could see deviation from HWE with a Wahlund effect (WAHLUND, 1928). This indicates that populations were isolated from each other and $k d r$ occurrence seems to be an independent effect probably reflecting the insecticide strategy used by each ranch. Multiple independent origins of $k d r$ mutation appear to occur also in other organisms (ANSTEAD et al., 2005; ALON et al., 2006). In the same region, it is possible to find a population with a very low $k d r$ allelic frequency and another one with relatively high frequency, as seen in the Central-West region; even in the same county (Corumbá, State of Mato Grosso do Sul, Central-West region), the percentage of $k d r$ allelic frequency varied from 2 to 32 .

McDonald and Schmidt (1987) reported that resistance to pyrethroids was sex-linked but although the resistance gene was equally effective in both sexes, adult males were more susceptible than females (McDONALD; SCHMIDT, 1990). Li et al. (2003) in part corroborated those results, after the screening of $k d r$ in horn flies from Mexico and USA, the $k d r$ allelic frequency in horn flies from Mexico were 23.2-37.8\% higher in females than males, but there was no difference in the flies from USA, as also seen in Brazilian flies.

Behavioral and metabolic mechanisms have been associated with pyrethroid insecticide resistance in horn flies (LOCKWOOD et al., 1985; SHEPPARD, 1995). However, the structural change that leads to the target site insensitivity mediated by the $k d r$ gene is considered 
to be a major event (BULL et al., 1988; SPARKS et al., 1990). Interestingly, although resistance to pyrethroids is disseminated throughout Brazil, only $48 \%$ of the resistant populations had $k d r$ flies and their frequency in resistant populations was quite low.

Although low $k d r$ frequency among resistant populations could be associated to fitness cost (SCOTT et al., 1997), Guglielmone et al. (2002) found that fitness cost was not enough to control resistance spread, but only slowly reduce resistance when pyrethroids were not in use.

Despite these explanations for the low frequency of $k d r$, it is possible to affirm that there is at least another mechanism playing an important role in resistance to pyrethroids in some horn fly populations.

Further studies are necessary to better understand the importance of $k d r$ as well as to explore other mechanisms of resistance of horn flies to pyrethroids in Brazil. This study shows that, with the apparent exception of the Northeast region, the $k d r$ mechanism associated with the pyrethroid resistance occurs all over Brazil.

\section{References}

ALJANABI, S. M.; MARTINEZ, I. Universal and rapid salt-extraction of high quality genomic DNA for PCR-based techniques. Nucleic Acids Research, v. 25, n. 22, p. 4692-4693, 1997.

ALON, M. et al. Multiple origins of pyrethroid resistance in sympatric biotypes of Bemisia tabaci (Hemiptera: Aleyrodidae). Insect Biochemistry and Molecular Biology, v. 36, n. 1, p. 71-79, 2006.

ANSTEAD, J. A.; WILLIAMSON, M. S.; DENHOLM, I. Evidence for multiple origins of identical insecticide resistance mutations in the aphid Myzus persicae. Insect Biochemistry and Molecular Biology, v. 35, n. 3, p. 249-256, 2005.

ARMICHOT, M. et al. Target modification as a molecular mechanism of pyrethroid resistance in Drosophila melanogaster. Pesticide Biochemistry and Physiology, v. 44, n. 3, p. 183-190, 1992.

BARROS, A. T. M. Situação da resistência da Haematobia irritans no Brasil. Revista Brasileira de Parasitologia Veterinária, v. 13, Supl. 1, p. 109-110, 2004.

BULL, D. L.; HARRIS, R. L.; PRYOR, N. W. The contribution of metabolism to pyrethroid and DDR resistance in the horn fly (Diptera: Muscidae). Journal of Economic Entomology, v. 81, n. 2, p. 449-458, 1988.

CAMPBELL, J. B. Effect of horn fly control on cows as expressed by increased weaning weights of calves. Journal of Economic Entomology, v. 69 , n. 6 , p. 711-712, 1976.

CAMPBELL, J. B.; THOMAS, G. D. The History, Biology, Economics and Control of the Horn Fly, Haematobia irritans. Agri-Practice, v. 13, n. 4, p. 31-36, 1992.

DONG, K. E.; SCOTT, J. G. Linkage of $k d r$-type resistance and the para homologous sodium channel gene in German cockroaches (Blattella germanica). Insect Biochemistry and Molecular Biology, v. 24, n. 7, p. 647-654, 1994.

GRISI, L. et al. Impacto econômico das principais ectoparasitoses em bovinos no Brasil. A Hora Veterinária, v. 21, n. 125, p. 8-10, 2002.

GUERRERO, F. D. et al. Toxocological and molecular characterization of pyrethroid-resistant horn flies, Haematobia irritans: Identification of $k d r$ and super- $k d r$ point mutations. Insect Biochemistry and Molecular Biology, v. 27, n. 8/9, p. 745-755, 1997.

GUERRERO, F. D.; KUNZ, S. E.; KAMMLAH, D. Screening of Haematobia irritans irritans (Diptera: Muscidae) populations for pyrethroid resistance-associated sodium channel gene mutations by using a polymerase chain reaction assay. Journal of Medical Entomology, v. 35, n. 5, p. 710-715, 1998.

GUGLIELMONE, A. A. et al. Skin lesions and cattle hide damage from Haematobia irritans infestations. Medical and Veterinary Entomology, v. 13, n. 3, p. 324-329, 1999.

GUGLIELMONE, A. A. et al. Toxicity of cypermethrin and diazinon to Haematobia irritans (Diptera: Muscidae) in its American southern range. Veterinary Parasitology, v. 101, n. 1, p. 67-73, 2001.

GUGLIELMONE, A. A. et al. Dynamics of cypermethrin resistance in the field in the horn fly, Haematobia irritans. Medical and Veterinary Entomology, v. 16, n. 3, p. 310-315, 2002.

KINZER, H. G. et al. Influence of horn flies (Haematobia irritans) on weight loss in cattle with notes on prevention of loss by insecticide treatment. Southwestern Entomologist, v. 9, n. 2, p. 212-217, 1984.

KUNZ, S. E.: ESTRADA, M. O.; SANCHEZ, H. F. Status of Haematobia irritans (Diptera: Muscidae) Insecticide Resistance in Northeastern Mexico. Journal of Medical Entomology, v. 32, n. 5, p. 726-729, 1995.

LI, A. Y. et al. Survey of resistance to permethrin and diazinon and the use of a multiplex PCR assay to detech resistance alleles in the Horn Fly, Haematobio irritans irritans (L.). Journal of Medical Entomology, v. 40, n. 6, p. 942-949, 2003.

LOCKWOOD, J. A. et al. Behavioral resistance to the pyrethroids in the horn fly, Haematobia irritans (Diptera: Muscidae). Environmental Entomology, v. 14, n. 6, p. 873-880, 1985.

MÁRQUEZ, L. et al. Primer diagnóstico de resistencia de Haematobia irritans (Diptera: Muscidae) en Uruguay. Determinación de susceptibilidad a cypermetrina y diazinón. Veterinaria (Uruguay), v. 33, n. 133 , p. 20-23, 1997.

McDONALD, P. T.; SCHMIDT, C. D. Genetics of permethrin resistance in the horn fly (Diptera: Muscidae). Journal of Economic Entomology, v. 80, n. 2 , p. $433-437,1987$.

McDONALD, P. T.; SCHMIDT, C. D. Linkage, expression and distribuition of the pyrethroid resistance gene in the horn fly (Diptera: Muscidae). Journal of Economic Entomology, v. 83, n. 5, p. 1718-1722, 1990.

McDONALD, J. H.; VERRELLI, B. C.; GEYER, L. B. Lack of geographic variation in anonymous nuclear polymorphisms in the American oyster, Crassostrea virginica. Molecular Biology and Evolution, v. 13, n. 8, p. 1114-1118, 1996.

MIYASAKI, M. K. et al. Cloning and sequencing of the para-type sodium channel gene from susceptible and $k d r$-resistant German cockroaches (Blatella germanica) and house fly (Musca domestica). Molecular and General Genetics, v. 252, n. 1-2, p. 61-68, 1996.

SCOTT, J. A.; PLAPP, Jr., F. W.; DARRELL, E. B. Pyrethroid resistance associated with decreased biotic fitness in horn flies (Diptera: Muscidae). Southwestern Entomologist, v. 22, n. 4, p. 405-410, 1997.

SHEPPARD, D. C. Oxidative metabolic resistance to cyanopyrethroids in the horn fly (Diptera: Muscidae). Journal of Economic Entomology, v. 88, n. 6, p. 1531-1535, 1995. 
Sindicato Nacional da Indústria de Produtos para a Saúde Animal -SINDAN. Compêndio de Produtos Veterinários, 2005. Disponível em: <http://www. cpvs.com.br/cpvs/index.html>. Acesso em: 15 de Agosto 2005.

SPARKS, T. C. et al. Insecticide resistance in the horn fly, Haematobia irritans. Journal of Agricultural Entomology, v. 2, n. 3, p. 217-233, 1985.
SPARKS, T. C. et al. Permethrin metabolism in pyrethroid -resistant adults of the horn fly (Muscidae: Diptera). Journal of Economic Entomology, v. 83, n. 3, p. 662-665, 1990.

WAHLUND, S. Composition of populations from the perspectiva of the theory of heredity. Hereditas, v. 11, n. 1, p. 65-105, 1928. 